\title{
DIMENSI KOMUNIKASI BIMBINGAN DAN KONSELINGUNTUK MENINGKATKAN EFEKTIVITAS PEMBERIAN BANTUAN
}

\author{
${ }^{1}$ Suhe rman \\ ${ }^{1}$ Universitas Pendidikan Indonesia \\ Email: suhermanbkupi@yahoo.co.id
}

\begin{abstract}
Growing komunikasiefektifantara konselingdengan guidance teachers and students is a precondition for achieving the purpose of guidance and counseling in schools. Disampingitu, quality communication, psychologically will stimulate students to involve themselves intensively in the process of providing this bantuan.Kondisiakanmendorong students to open themselves to understand the personal characteris tics, permasalahanyang faced, and willing to work together to explore various alternatives for self-development, making choices, and troubleshooting. Less exposure of students to guidance and counseling teachers dilatarbelakangioleh berbagaifaktor, including suspected karenarendahnya BK teachers' professional capabilities in developing communications that facilitate the provis ion of as sistance for students. In relation to that, teachers need to have the competence BK communication, in order to improve the effectiveness of aid in guidance and konseling.Dimensi-dimen sional communication shall include: (a) the behavior of empathy, (b) the acceptance and respect of students, (c) the warmth and attention, (d) openness and sincerity, and (e) concreteness and specificity of expression.
\end{abstract}

Keywords : quality communication, preconditions, professional competence, self-development

\section{A. Pendahuluan}

Salah satu tujuan bimbingan dan konseling sekolah adalah membantu siswa untuk mengembangkan diri, memiliki kemandirian, dan tanggung jawab dalam mengambil pilihan dan keputusan, sehingga siswadapat menghadapi masa depan secara terarah. Siswa diharapkan memiliki kepribadian yang efektif, kreatif, dan produktif, serta mampu berinteraksi, menyesuaikan diri, dan mengembangkan lingkungan kehidupan sebagai fasilitas perkembangan yang kondusif.

Layanan bimbingan dan konseling berupaya membantu siswa agar mereka dapat menjalani proses belajar secara efektif dan mandiri.Siswa diharapkan memiliki ketangguhan dan kemampuandalam menghadapi berbagai peluang, mengatasi kendala kehidupan,dan responsif dalam menghadapi kesempatan yang muncul untuk mengaktualisasikan potensi-potensi yang mereka miliki.Dalam era kesejagatan ini, individu dituntut untuk selalu memperbaiki kemampuan dan kecakapannya dalam memilih informasi sehingga dapat mengambil pilihan dan keputusan secara tepat.

Sebagai pelaksanabimbingan dan konseling di sekolah,guru BK perlu memperhatikan adanya kompleksitas kehidupan masyarakat serta berbagai persoalan yang mungkin ditimbulkannya, yang berimbas pada kehidupan remaja. Guru BK seyogianya tertantang untuk menyelenggarakan layanan bimbingan dan konseling yang berorientasi untuk memenuhi tuntutan dan kebutuhan perkembangan siswa sesuai dengan nilai-nilai yang hidup dimasyarakat tempat para siswa menjalani perkembangannya. Bimbingan dan konseling perlu menyelenggarakan layanan yang berkualitas, baik dilihat dari segi substansi materi, maupun dilihat dari strategi pelaksanaan layanannya. 
Tuntutan akan kualitas layanan bimbingan dan konseling yang profesional di atas,mengimplikasikan perlunya guru BK menguasai sejurnlah kompetensi bimbingan, baik berupa pengetahuan, keterampilan, maupun etika profesional. Selain itu, mereka juga seyogianya memiliki sejumlah kualitas pribadi yang dapat mendukung perannya sebagai guru bimbingan dan konseling di sekolah.Kompetensi pengetahuan, keterampilan, pribadi, maupun etika profesional, akan menentukan kinerja seorang guru BK yang akan tampak pada saat memberikan bantuan melalui proses komunikasi dengan siswa.

Keberhasilan layanan bimbingan dan konseling di sekolah perlu diawali dengan adanya kesediaan dan keterbukaan siswa untuk secara aktif terlibat dalam proses bimbingandan konseling. Keterbukaan merupakan dimensi yang sangat mendasar bagi keberhasilan layanan bimbingan dan konseling. Kondisi seperti itu akan terjadi apabila guru bimbingan dan konseling mampu mengembangkan hubungan interpersonal yang kondusif sesuai dengan harapan siswa.

Terciptanya komunikasiguru bimbingan dan konseling dengan siswa yang berkualitas dan sesuai dengan harapan siswa merupakan landasan, dan akan memberikan pengaruh positif bagi terselenggaranya layanan bimbingan dan konseling di sekolah. Disamping dapat mengundang siswa untuk melibatkan diri secara aktif dalam proses bimbingan, kondisi hubungan yang fasilitatifdapat memotivasi siswa untuk melakukan berbagai upaya yang diperlukan guna mencapai tujuan yang ingin diraihnya. Proses bimbinganakanterfasilitasi apabila siswa lebih terbuka dalam membahaspersoalan-persoalan yang dihadapi, sehingga tumbuh kerjasama dalam merumuskan pemecahan masalah dan pengembangan dirinya.

Kurang berkembangnyakomunikasi
siswa dengan guru bimbingan dan konselingdapat disebabkan oleh sejumlah faktor. Namun, semua itu pada akhimya akan bermuara pada kemampuan profesional guru bimbingan dan konseling dalam mengembangkan kondisi yang komunikatif dalam layanan bimbingan dan konseling.

Untuk keberhasilan layanannya, guru bimbingan dan konseling harus berupaya secara sungguh-sungguh mengembangkan komunikasi yang efektif dengan siswa. Tanpa itu, layanan bimbingan dan konseling akan mengalami kegagalan.Dengan tumbuhnyakomunikasi yang memfasilitasi siswa, akan berkembang kepercayaan siswa terhadap bantuan yang diberikan oleh guru bimbingan dan konseling di sekolah. Tujuan dari studi ini diantaranya mencakup:

a. Memperoleh pemahaman tentang dimensi-dimensi komunikasi efektif dalam bimbingan dan konseling agar guru BK dapat memberikan bantuan secara efektif dalam layanan bimbingan dan konseling di sekolah.

b. Mengeksplorasi strategi pengembangan kecakapan komunikasibagi Guru BK dalam layanan bimbingan dan konseling di sekolah.

\section{B. KAJIAN LOTERATUR}

Bimbingan dan Konseling sebagai Proses Komunikasi

Bimbingan dan konseling merupakan layanan yang sangat mendasar dalam proses pendidikan.Peranan penting bimbingan dan konseling dalam membantu siswa antara lain dalam menetapkan pilihan dan mengambil keputusan, mengatasi permasalahan, dan memfasilitasi siswa dalam mengembangkan potensi-potensi yang mereka miliki.

Layanan bimbingan dan konseling berupaya membantu siswa dapat memanfaatkan kesempatan dan peluang yang tersedia secara maksimal, dan meminimalkan berbagai hambatan yang mungkin terjadi dalam menjalani proses perkembangannya. Indikator keberhasilan layanan bimbingan dan konseling adalah tercapainya perwujudan diri. Siswa dapat 
menjalani kehidupan secara efektif dan produktif serta terhindar dari kehampaan.

$$
\text { Bimbingan dan konseling }
$$

berlangsung dalam proses interaksi antara guru bimbingan dan konseling dengan siswa, yang bertujuan membantu siswauntuk: (1) memahami, menerima, mengarahkan, dan mengembangkan minat, bakat, dan kemampuan secara optimal, (2) menyesuaikan diri dengan keadaan lingkungan keluarga, sekolah, dan masyarakat, dan (3) merencanakan kehidupan masa depan yang sesuai dengan tuntutan dunia pada saat ini maupun di masa yang akan datang.

Komunikasi bimbingan dan konselingdalam tulisan ini merujuk pada konsep "helping-relationship" yang dikemukakan oleh Brammer (2003 : 40). Konsep ini dapat dimaknai sebagai komunikasi pemberian bantuan dalam layanan bimbingan dan konseling. Dalarn komunikasi pemberian bantuan terdapat dua subyek yang terlibat, yaitu: guru bimbingan dan konseling/konselor(orang yang memberi bantuan), dan siswa/konseli(orang yang menerima bantuan).

Berdasarkan pengertiantersebut, bantuan yang diberikan oleh guru bimbingan dan konseling diarahkan agar siswa tumbuh dan berkembang, yaitu munculnya kesadaran bahwa banyakstrategi yang dapat dipilih dalam proses pengembangan diri, merasa tenteram dalam membuat keputusan, mampu memecahkan masalah, dan mampu mengekspresikan perasaan dan kemampuan yang dimilikinya. Kondisi ini akan terjadi apabila kepribadian guru bimbingan dan konseling, karakteristik, sikap serta orientasi nilai, dan keterampilan memahami siswa, memberikan alternatif pemecahan masalah, dan mampu memfasilitasi siswa untuk tumbuh dan berkembang. Dengan komunikasi bimbingan dan konselingyang efektif, siswa diharapkan dapat menjalanikehidupan yang lebih bermakna.

Komunikasi bimbingan dan konseling cukup sulit untuk didefinisikan karena hubungan yang dimaksud ditentukan oleh orientasi nilai yang dianut oleh masingmasing pihak, guru bimbingan dan konseling dan siswa, juga oleh situasi yang muncul pada saat pemberian bantuan berlangsung.

Bimbingan dan konselingsebagai proses komunikasi, menunjukkan bahwa suatu hubungan dapat dikatakan membantu apabila : (a) dapat memfasilitasi konseli(siswa) untuk tumbuh dan berkembang, terutama munculnya kesadaran diri betapa banyak alternatif yang dapat ia pilih untuk menuju hidup dengan bahagia dan memiliki kesiapan untuk berperilaku sesuai dengan alternatif pilihan terbaiknya, (b) bantuan itu terjadi karena adanya persetujuan (agreement) sebagai kontrak psikologis guru bimbingan dan konseling dengan siswa, (c) bantuan itu dapat memenuhi harapan dan kebutuhan siswa.

Bantuan yangdiberikan kepada siswa bertujuan agar dapat mengaktualisasikan diri dengan penuh kebahagiaan dan bermakna baik bagi dirinya maupun bagi lingkungannya. Helping people can be counstrued as a process of assisting konselis toward higher levels of selfactualization and the joyful realization of their unused possibilities. Secara skematik, proses bantuan dapat dianalisis dari empat dimensi, (a) personality of helper, (b) helping skills, (c) growth - facilitating condition, dan (d) specific outcome Brammer (2003 : 40).

Lebih lanjut proses membantu tersebut dapat dipetakan dalam bagan berikut.

\begin{tabular}{|c|c|c|c|}
\hline $\begin{array}{l}\text { Personali } \\
\text { ty of }\end{array}$ & $\begin{array}{l}\text { Helping } \\
\text { Skills }\end{array}$ & $\begin{array}{l}\text { Growth - } \\
\text { Facilitating }\end{array}$ & $\begin{array}{l}\text { Specific } \\
\text { Outcomes }\end{array}$ \\
\hline Traits & $\begin{array}{l}\text { For } \\
\text { Understandin }\end{array}$ & Trust & For the person \\
\hline Attitudes & For comfort & Respect & For society \\
\hline Values & For Action & Freedom & For the Guru \\
\hline
\end{tabular}

Bagan 2.1.Proses Bantuan

(Dikutip dari Brammer (2003 : 40).

Keberhasilan proses bantuan sangat dipengaruhi oleh kepribadian guru bimbingan dan konseling dan keterampilannya dalam memberikan 
bantuan. Kedua faktor tersebut akan menjadi fasilitator bagitumbuhnya kesadaran siswa, ia menyadari begitu banyak alternatif pengembangan diri dan pemecahan masalah yang dapat dipilih. Kesadaran inilah yang akanmendasari proses pengambilan keputusan secara tepat melalui komunikasi bimbingan dan konseling. Lebih jauh lagi keputusan tersebut akan menimbulkan dampak yang spesifik sebagai hasil dari komunikasi bimbingan dan konseling, baik bagi perkembangan pribadi individu, masyarakat, dan guru bimbingan dan konseling itu sendiri.

Terdapat tiga dimensi kepribadian guru bimbingan dan konseling yang terkait dalam proses komunikasi bimbingan dan konseling. Traits yaitu ciri-ciri pribadi guru bimbingan dan konseling yang meliputi kemampuan, bakat, dan minat untuk memberikan bantuan terliadap orang lain. Attitudes yaitu sikap dan prilaku guru bimbingan dan konseling baik ketika memberikan bantuan maupun pada lingkup hidup lainnya. Values yaitu onentasi nilai guru bimbingan dan konseling yang akan mewarnai kriteria penilaian suatu bantuan yang diberikannya. Orientasi nilai siswa harus dijadikan rujukan yang kongruen dengan orientasi nilai guru bimbingan dan konseling.(Brammer , 2003 : 5),

Ada tiga keterampilan guru bimbingan dan konseling dalam mengembangkan komunikasi bimbingan dan konseling. Pertama.,keterampilan memahami dan memberikan pemahaman tentang diri dan permasalahan siswa. Guru BK perlumemahami siswa dengan segala karakteristik dan permasalahannya.Disamping itu, siswa perlu mendapat bantuan guru bimbingan dan konseling untuk memperoleh kesadaran bahwa ia memiliki potensi untuk berkembang, dan pemahaman bahwa ia memiliki masalah.

$$
\text { Kedua, kemampuan untuk }
$$
membantu siswa membuat beberapa alternatif sebagai solusi dari masalah yang dihadapi dan pengemhangan potensi dirinya. Keterampilan ini mengarahkan siswa agar mampu mengambil keputusan secara tepat.

Ketiga, keterampilan membantu siswa agar siap melakukan dan sanggup menerima segala konsekuensi dari keputusan yang diambilnya.

Terdapat tiga kondisi yang memfasilitasi siswa bagi tumbuhnya kesadaran diri, merasa tenteram dalam membuat keputusan, mampu memecahkan masalah, dan merasa bebas dalam mengekspresikan perasaan. Ketiga kondisi tersebut adalah trust (kepercayaan), respect (penghargaan dan penghormatan), freedom (kebebasan).

\section{METODE PENELITIAN}

Metode penelitian yang digunakan dalam penelitian ini adalah metode dedskriptif analitik terhadap fenomena perilaku siswa dalam berkomunikasi selama mengikuti pembelajaran di sekolah.

\section{HASIL DAN PEMBAHASAN}

Keberhasilan layanan bimbingan dan konseling dapat dicapai apabila guru BK mampu mengembangkan komunikasi efektif dengan siswa. Perilaku-perilaku guru bimbingan dan konseling tersebut merupakan prasyarat untuk mencapai tujuan bimbingan dan konseling yang dikembangkannya. Kompetensi komunikasi dimaksud meliputi: (1) perilaku empatik, (2) penerimaan dan penghargaan terhadap siswa, (3) kehangatan dan perhatian, (4) keterbukaan dan ketulusan, dan (5) kekonkretan dan kekhususan ekspresi.

\section{a. Perilaku Empatik}

Empati merupakan kemampuan untuk memahami siswa dan mencoba menggugah siswa bahwa ia dipahami oleh guru BK. Dalam perlakuan empati, guru BK berupaya untuk menempatkan diri pada dunia siswa dengan menggunakan rangka rujukan siswa(client frame of reference). Proses penempatan diri seperti itu, oleh disebut sebagai gerakan 
eksternal ke internal (external to internal movement). (Brammer, 2003: 42)

Tolok ukur keberhasilan empati guru BK adalah kemampuan siswa untuk menggunakan pemahaman empati guru BK untuk memahami dirinya. Pemahaman empati tidak cukup dialami dan dirasakan oleh guru BKsaja, melainkan pemahaman tersebut harus pula dirasakan dan dialami sendiri oleh siswa. Empati adalah ...to be helped a client must be understood. Further this undestanding must be communicated. A client must known what you are listening carefuly and that your understand is this does to put your self in another's shoes. (Brammer, 2003)

Terdapatlimaperilaku empati guru bimbingan dan konseling. Pertama, guru bimbingan dan konseling meninjau permasalahan dari sudut pandang siswa, dan berusaha menempatkan diri pada posisi dan kerangka berpikir siswa. Dengan memposisikan diri seperti ini, guru bimbingan dan konseling akan mampu mengungkapkan masalah siswa sebagaimana yang siswa rasakan. Kedua, guru bimbingan dan konseling merasa bersama dengan siswa, sehingga ia peduli terhadap perkembangan diri siswa dan mau memperhatikan secara keseluruhan ungkapanungkapan siswa. Ketiga, setelah melalui dua prilaku empati di atas, guru bimbingan dan konseling mulai membantu siswa untuk memahami masalah yang dialaminya. Guru bimbingan dan konseling berupaya menuntun siswa untuk memahami diri serta permasalahannya.

Keempat, meski guru bimbingan dan konseling sudah berada dalam posisi dan kerangka berpikir siswa, ia tetap konsisten dengan jati dirinya. Guru bimbingan dan konseling tidak kehilangan jati diri dalam posisinya untuk memberikan bantuan.Kelima, melalui keempat prilaku empati di atas, guru bimbingan dan konseling seyogianya mampu menafsirkan ungkapan siswa secara tepat. Bahkania mampu mengarahkan siswa untuk menyimpulkan permasalahan yang dihadapinya melalui dorongan dari ungkapan guru bimbingan dan konseling.Para ahli cenderung setuju bahwa empati merupakan hal yang amat penting dan esensial dalam proses konseling. Begitu pentingnya perilaku empati dalamkomunikasi bimbingan dan konseling, sehingga empati merupakan jantung dari proses komunikasi bimbingan dan konseling yang efektif.

\section{b. Penerimaandan Penghargaan}

Penerimaan dan penghargaan terhadap siswa sebagaimana adanya akanmenempatkan siswa sebagai individu fungsional. Ini merupakan perwujudan dari pengakuan individualitas dan penghargaan diri siswa sebagai manusia. Menurut Rogers, kondisi ini disebut sebagai unconditional positive regard ditafsirkan sebagai "... the complete acceptence of all the client's characteristics and behaviors ... (Osipow, Wals and Tosi, 1980: 19). Dalam Egan (2002), unconditional postive regard and resfect, dapat dimaknaia non judgmental and nonreservation attitude yaitu sikap yang tidak memberikan penilaian dan penerimaan tanpa syarat terhadap siswa. Carkhuff (1983:69) menyebutnya dengan communicate unconditonal regard yang berati jalinan komunikasi tanpa syarat yaitu penerimaan terhadap siswa sebagaimana adanya.

Uraian di atas menunjukkan bahwa yang dimaksud dengan penerimaan dan penghargaan dalam mengembangkan komunikasi bimbingan dan konseling adalahjalinan komunikasi yang menerima siswa apa adanya yang mengimplikasikan bahwa siswa dipandang sebagai pribadi yang bermakna dan berguna secara tulus. Konsep ini menuntut tindakan guru bimbingan dan konseling bukanlah sebagai pengendali tetapi terarah sebagai fasilitator perkembangan siswa.

Diyakini bahwa dengan penerimaan dan penghargaan yang tulus, maka siswa akan mampu mengekspresikan perasaan dan permasalahannya. Penerimaan dan penghargaandapat diekspresikan dengan ungkapan yang tulus, penerimaan, dan empati

\section{c. Kehangatan dan Perhatian}


Kehangatan dan perhatian adalah suatu kondisi penuh persahabatan yang ditunjukkan dengan ekspresi non-verbal seperti senyuman, kontak mata, dan perilaku non-verbal lainnya.Kondisi ini sebagai warmth and caring. Brammer (2003:38) menegaskan bahwa "warmth is condition of friendliness and considerateness manifested by smilling, eye contact,and nonverbal attending behavior".

Gurubimbingan dankonseling dituntut untuk menunjukkan keterlibatan emosi dengan suasana hubungan yang hangat dan penuh perhatian. Dengan adanya kehangatan dan perhatian yang tulus, siswa akan merasa aman, nyaman dan tenteram untuk mengadakan komunikasi dengan guru bimbingan dan konseling. Karena begitu pentingnya kehangatan dan perhatian dalam komunikasi bimbingan dan konseling, kaum Freudian memandang bahwa kehangatan dan perhatian merupakan kekuatan yang sangat berarti dalam proses komunikasi bimbingan dan konseling. (Frank A. Nugent, 2001).

Untuk menciptakan kondisiwarmth (kehangatan), sikap duduk mengarah kepada siswa dan responsif kepadanya merupakan hal yang esensial. Dalam kontak mata, guru bimbingan dan konseling hendaknya memandang siswa secara spontan tetapi menunjukkan adanya perhatian dan keinginan untuk mendengarkan dan merespon pernyataan-pernyataan siswa. Ekspresi wajah guru bimbingan dan konseling tidak kaku, tidak dingin, dan sama sekali tidak ada kesan menyeramkan.

Berdasarkan uraian di atas, dapat disimpulkan bahwa indikator komunikasi yang hangat dan penuh perhatian guru BK pada saat mengembangkan komunikasi bimbingan dan konseling adalah : (a) memperlakukan siswa secara bersahabat, (b) menunjukkan kepedulian terhadap perkembangan dan masalah siswa, (c) membantu melancarkan ungkapan-ungkapan siswa, (d) memelihara perhatian penuh kepada siswa, dan (e) mengungkapkan kembali pernyataan siswa secara tepat.

\section{d. Keterbukaan dan Ketulusan}

Keterbukaan mengandung arti bahwa guru bimbingan dan konseling mengembangkan sikap yang menunjukkan kondisi apa adanya. Dalam pengertian lain, keterbukaan adalah perilaku yang menunjukkan keaslian, sesuai dengan keadaan yang sebenarnya,tidak melebih-lebihkan, tidak menutup-nutupi keberadaan dirinya, serta memiliki sikap terbuka untuk dipuji, dikritik, dan terbuka atas berbagai masukan dari oranglain.

Bergin dan Galfield (1999)
mengartikan keterbukaan sebagai suatu pernyataan dimanakata-kata guru bimbingan dan konseling konsisten dengan perilakunya. Sedangkan Tyler mengartikan keterbukaan adalah kemauan untuk mencoba mengetahui dan memahami masalah siswa, Menurut Combs, keterbukaan guru bimbingan dan konseling terhadap siswa dalam komunikasi bimbingan dan konseling dilandasi oleh adanya sikap saling mempercayai.

Untuk menunjukkan kondisi yang terbuka, pada saat melakukan komunikasi bimbingan dan konseling, Egan (1982: 132) memberikan rambu-rambu sebagai berikut: (1) guru bimbingan dan konseling jangan terlalu bersikap formal-profesional, berbuatlah spontan tetapi tidak sembarangan, (3) jangan menunjkkan sikap mempertahankan diri, (4) berusaha untuk tetap konsisten, (5) guru bimbingan dan konseling bersikap bjaksana,dan (6) berbagi pengalaman dengan siswa.Carkhuff (1983) membagi dua tahapan perilaku keterbukaan dan ketulusan, yaitu: tahapanresponsive set (tahap mendengarkan dan memperhatikan siswa), tahapan initiative set (tahap pengambilan inisiatif dengan proses modeling).

Keterbukaan dan ketulusan sedikit berbeda dengan aspek-aspek komunikasi bimbingan dan konseling lainnya. Keterbukaan lebih bersifat non-verbal, sedangkan aspek lainnya lebih bersifat verbal Konsekuensinya keempat aspek lebih mengarah kepada 
skillverbal sedangkan ketulusan dan keterbukaan akan sangat tergantung kepada kejujuran, apakah seorang guru bimbingan dan konseling betul-betul tulus dan terbuka dalam memberikan layanannya.

Mengacu kepada uraian di atas, keterbukaan dan ketulusan dapat dilihatdengan menganalisis lima indikator kemampuan guru bimbingan dan konseling dalam hal: (a) memberikan kebebasan kepada siswa untuk berekspresi dalam mengemukakan pikirandan perasaannya, (b) menumbuhkan kepercayaan kepada siswa bahwa guru bimbingan dan konseling dapat membantunya dalam proses pengembangan diri dan pemecahan masalah, (c) menampilkan perilaku yang tidak dibuat-buat, (d) menanggapi sifatsifat yang positif dan negatif siswa secara bijaksana dan konstruktif, dan (e) berupaya untuk konsisten antara perbuatan dengan ucapannya.

\section{e.Kekonkretan dan Kekhususan Ekspresi}

Kekonkretan dan kekhususan ekspresi merupakan aspek yang penting dalam komunikasi bimbingan dan konseling. Ditegaskan ole Ivey dan Authier bahwa, ...specifity of expression is important in effective helping session. (Brammer, 2003: 42).

Kekonkretan dan kekhususan ekspresi merupakan keakuratan dan kejelasan kumunikasi Dengan tilikan yang berbeda, Carkhuff(1983) menjelaskan lima pengertian tentang kekonkretan sesuai dengan tahapan proses bantuan yang dilakukannya. Pertama, pada tahap attending (prehelping), kekonkretan dan kekhususan diartikan sebagai meeting concrete needs, yaitu mempertemukan kebutuhan siswa secara jelas. Kedua pada tahap responding disebut sebagai dealing with specific experience, yaitu proses mengarahkan suatu pengalaman siswa. Ketiga, tahappersonalizing disebut sebagai concretizing problems, yaitu proses memperjelas masalah. Keempat, pada tahap initiating disebut sebagai being fully specific, yaitu proses spesifikasi
masalah.Kelima, pada tahap helping disebut sebagai being pragmatic, yaitu membuat praktis suatu solusi yang diambil siswa.

Kekonkretan dan kekhususan ekspresi lebih mengarah kepada komunikasi verbal. Kondisi ini mengisyaratkan adanya kejelasan ungkapan guru bimbingan dan konseling sehingga mudah dipahami siswa. Guru bimbingan dan konseling memusatkan pembicaraan pada perasaan, pemikiran, dan pengalaman siswa. Selain itu, guru BK perlu berupaya untuk berkomunikasi secara teliti dan jelas serta mau memperjelas pernyataan siswa.

Dengan kekonkretan komunikasi, siswaakanterhindar dari kecemasan, kebingungan,dankekesalan.Kejelasan komunikasi antara guru BK dengan siswa merupakan aspek yang esensialbagi efektivitas pemberian bantuan. Blander and Grinder menyatakan .... indicate how helping clarifies konseli sentences, give konselis better wayto describe themselves, and provides them with sharper descriptive thoughts abouttheir problems. (Brammer, 2003: 78).

\subsection{PengembanganKompetensi Guru Bimbingan dan Konseling}

Guru bimbingan dan konselingperlu memiliki kualitas profesional dengan didukung oleh lima kompetensi, yaitu: (a) dorongan untuk menampilkan perilaku yang mendekati standarideal, (b) meningkatkan dan memelihara citra profesi, (c) keinginan untuk senantiasa mengejar kesempatan pengembangan profesional yang dapat meningkatkan dan memperbaiki kualitas pengetahuan dan keterampilan, (d) mengejar kualitas dan cita-cita profesi dan (e) memiliki kebanggaan terhadap profesinya.

Terdapat tiga kelompok kompetensi yang seyogianya dikembangkan dalam pendidikan calon guru bimbingan dan konseling meliputi hathal beikut.

1) Kemampuan profesional apa yang harus dimiliki guru bimbingan dan konseling sebagai seorang pribadi?

2) Kemampuan profesional apa yang harus 
dimiliki guru bimbingan dan konseling dalam menciptakan situasi yang menimbulkan pengaruh?

3) Kemampuan profesional apayang harus dimilki guru bimbingan dan konseling agar siswa mau meminta dan menerima bantuan guru BK? (Shertzer dan Stone, 1981; 42)

\section{E. SIMPULAN DAN REKOMENDASI}

Dalam pemberian layanannya,guru bimbingan dan konseling perlu menciptakan situasi yang menimbulkan pengaruh dengan memiliki keterampilan-keterampilan untuk mengembangkan komunikasi bimbingan dan konseling. Keterampilan tersebut meliputi: (1) keterampilan untuk memahami siswadan memberikan pemahaman kepadanya agar ia menyadari akan masalahnya dan mampu mengembangkan potensi diri (helping skills for understanding), (2) keterampilan untuk mengarahkan siswa kepada suatu proses pembuatan pilihan (helping skills for comfort), dan (3) keterampilan untuk memfasilitasi siswa agar mampu mengambil keputusan dan siap untuk melaksanakannya (helping skillsfor action).

Kompetensi komunikasi yang harus dimiliki guru bimbingan dan konseling agar siswa mau meminta dan menerima bantuan guru BK adalah kemampuan untuk menumbuhkan kepercayaan siswa kepada guru BK, kemampuan untuk menghargai siswa, dan kemampuan memberi kebebasan kepada siswa dalam mengekspresikan permasalahannya.

Dari studi ini ada beberapa rekomendasi untuk peningkatan kompetensi yang seyogianya dikuasai guru bimbingan dan konseling agar tercipta komunikasi yang menumbuhkan, meliputi: (1) keterampilan berempati, (2) keterampilan memberikan penghargaan terhadap pribadi siswa, (3)

Shetzer, Bruce dan Stone, S. (2000), Fundamental of Counselin, Boston : Houghton Mifflin Company

Yusuf, Syamsu LN.(2010), Psikologi Perkembangan Anak dan Remaja, Bandung : Rosda Karya keterampilan untuk menciptakan interaksi guru BK-siswa dengan nuansa emosional psikologis yang hangat dan penuh perhatian, (4)keterampilan untuk mengungkapkan pembicaraan secara tulus dan terbuka, dan (5) keterampilan mengemukakan pembicaraan secara konkret disertai kesesuaian ekspresi.

\section{F. DAFTAR RE FERENSI}

Blocher, DH. (2006), Developmental Counseling, New York : John Willey \& Son

Brammer, Lawrence M, (2003), The Helping Relationship Process and Skils, (SecondEdition), Englewood Cliffe, New Jersy: Prentice- Hail, Inc. Bruce Hosking

Egan, (2002), The Skilled Helper: Models, Skills, and Methodes for Effective Helping, Monterey California: Brooke Cole Publishing Company

Frank A. Nugent (2001), Professional Counseling, Belmont, California : Brooks Cole Publishing Company

Muro, J. James dan Kottman, Terry,(2005), Guidance and Counseling in the Elementary and Midde Schools, Agoura CA: Brown \& Benchmark

Myrick, Robert D. (2003),Developmental Guidance and Counseing : A Practical Approach (second Edition), Minneapolis : Educational Media Coorporation.

Shaw, M.E. \& Coustanzo, (1982), Theries of Social Psychology, Singapore: McGiaw-Hiil Book Company.

Schmidt, John J. (2004), Counseling in School Essential Service and Comprehensive Programs, Boston: Aliyah Bacon. 